\title{
KAJIAN STRUKTURAL SASTRA LISAN PEPACCUR MASYARAKAT LAMPUNG PEPADUN DALAM PROSESI PENGAMBILAN GELAR ADAT
}

\author{
Dewi Ratnaningsih dan Windo Dicky Irawan *)
}

\begin{abstract}
Pepaccur is a type of Lampung poetry which contains advice or message in the customary degree ceremony. In this research, data was collected from several regions belonging to the Lampung Abung community, such as Kotabumi Ilir, Blambangan Pagar, Surakarta, Bumi Agung, and Mulang Maya. The problem that will be examined in this study is about the structure contained in Pepaccur. The purpose and benefits of this study are (1) to determine the Pepaccur structure in the Pepadun community in the procession of taking traditional titles; (2) to revitalize Pepaccur Lampung Pepadun people. Descriptive method through qualitative approach is the method used in this study. Data collection techniques used in this study are (1) observation, (2) recording, and (3) interview. Data analysis techniques are carried out by identifying the Pepaccur structure. Based on ethnographic studies that are used as a foothold in this study the Pepaccur structure consists of a framework, diction, sound, tone, and class. (1) Pepaccur framework. Of the 6 Pepaccur text samples, there is only one Pepaccur text that does not have an opening stanza, ie in Pepaccur II text. In addition, the Pepaccur II text is also a text in the form of stories to bind Lampung women. (2) Pepaccur's diction. Based on the results of the analysis, the diction used by people who are Pepaccur is a diction related to marriage. (3) Pepaccur sounds. the sound found in Pepaccur text analysis is a sound pattern abc / abc, ab / ab, aa / aa, a / a. (4) Pepaccur tones. The tone in Pepaccur's text is advising. (5) figurative language. The figurative language found in the Pepaccur text includes; allegory, metaphor, and simile.
\end{abstract}

\section{Keyword: Pepaccur, Lampung Poetry, Language structure}

\section{A. PENDAHULUAN}

Sastra merupakan bagian yang tidak dapat dipisahkan dari masyarakat. Keberadaan sastra mengisyaratkan sisi kreativitas dan produktivitas dari masyarakat. Berdasarkan cara penyampaianya, sastra terbagi menjadi dua, yaitu sastra lisan dan sastra tulisan. Sastra lisan merupakan bentuk penyampaian sastra yang dilakukan secara langsung atau dari mulut ke mulut sedangkan sastra tulisan merupakan bentuk sastra yang disampaikan melalui untaian kata secara tertulis.

Dalam artikel ini akan dibahas sastra lisan pada masyarakat Lampung Pepadun dalam bentuk puisi, yaitu Pepaccur. Pepaccur merupakan jenis puisi Lampung yang di dalamnya terdapat nasihat atau pesan dalam upacara pemberian gelar adat (Sanusi, 2010:70). Masyarakat Pepadun terbagi atas empat daerah, yaitu: 1) Abung, 2) Tulang Bawang, 3) Way Kanan/Sungkai, dan 4) 
Pubiyan (Hadikusuma, 2009:5). Dalam penelitian ini akan dikhususkan masyarakat Lampung Abung sebagai objek penelitian. Masyarakat Lampung Abung tersebar di beberapa daerah. Dalam penelitian ini akan dilakukan pengambilan data dari beberapa daerah yang tergolong dalam masyarakat Lampung Abung, seperti Kotabumi Ilir, Blambangan Pagar, Surakarta, Bumi Agung, dan Mulang Maya.

Masyarakat Pepadun memiliki dua dialek, yaitu dialek A (api) dan $\mathrm{O}$ (nyo). Masyarakat Way Kanan/Sungkai menggunakan dialek A (api), dan masyarakat Abung dan Tulang Bawang menggunakan dialek $\mathrm{O}$ (nyo). Berdasarkan pembagian dialek tersebut, dapat diketahui bahwa objek dalam penelitian ini adalah Pepaccur berbahasa Lampung yang menggunakan dialek O (nyo). Pepaccur merupakan salah satu jenis puisi Lampung yang di dalamnya berisi tentang nasihat. Nasihat yang diberikan melalui Pepaccur dilakukan dalam prosesi pemberian gelar adat.

Pemberian gelar adat merupakan suatu tradisi turun-temurun yang dilakukan oleh masyarakat Lampung. Pemberian gelar adat dilakukan saat masyarakat Lampung melepas masa lajang (melakukan pernikahan). Pemberian gelar adat dapat dilakukan di tempat mempelai wanita maupun pria. Pemberian gelar adat di tempat wanita biasanya disebut dengan istilah ngamai adek/adok. Jika dilakukan di tempat pria, dikenal dengan istilah nandekken adek dan inai adek/nandokkon adok ghik ini adok. Melalui Pepaccur para orang tua akan memberikan nasihat-nasihat tentang kehidupan bermasyarakat maupun tentang kehidupan berumah tangga. Hal ini relevan dengan hasil penelitian dan pendapat Sukmawati dkk, (2014:2) bahwa pesan yang terdapat dalam Pepaccur berkenaan dengan kehidupan berumah tangga, bermasyarakat, berbangsa, bernegara, dan beragama. Selain itu, Sanusi (2010:71) mengatakan Pepaccur berisi nasihat tentang berumah tangga, bermasyarakat, berbangsa, bernegara, dan beragama.

Masalah yang akan dikaji dalam artikel ini adalah tentang struktur yang terdapat dalam Pepaccur. Pada dasarnya struktur Pepaccur sama dengan struktur puisi karena Pepaccur merupakan jenis dari puisi Lampung. Waluyo (2013:1) mengatakan puisi adalah karya sastra yang dipadatkan, dipersingkat, dan diberi irama dengan bunyi yang padu dan pemilihan kata-kata kias (imajinatif). Begitu juga Pradopo (2010:314) berpendapat bahwa puisi adalah ucapan atau ekspresi tidak langsung. Pepaccur dalam setiap teks memiliki struktur sebagaimana puisi pada umumnya. Siswantoro dalam Armina (2014:262) mengatakan unsur intrinsik puisi mencakup diksi, gaya bahasa, pencitraan, nada suara, ritme, rima, bentuk puisi, aliterasi, asonansi, konsonansi, hubungan makna, dan bunyi. 
Wolosky dalam Malik (2012:34), berpendapat bahwa struktur atau elemen dari puisi terdiri atas pilihan kata, susunan kata, bunyi, perhentian, imaji, dan bahasa kiasan. Berdasarkan pendapat para ahli, penelitian ini akan diarahkan pada struktur puisi berupa kerangka Pepaccur, pilihan kata (diction) dan susunan kata (sintax), bunyi (sound), nada (tone) dan bahasa kiasan (language of figures).

Tujuan dan manfaat penelitian ini adalah (1) untuk mengetahui struktur Pepaccur pada masyarakat Pepadun dalam prosesi pengambilan gelar adat; (2) untuk merevitalisasi Pepaccur masyarakat Lampung Pepadun. Metode deskriptif melalui pendekatan kualitatif merupakan metode yang digunakan dalam penelitian ini. Teknik pengumpulan data yang digunakan dalam penelitian ini adalah (1) Observasi, (2) Perekaman, dan (3) Wawancara.

\section{B. Struktur dalam Teks Pepaccur}

\section{Kerangka Pepaccur}

Syukur alhamdulilah
Tigeh judeumeu tano
Dendeng segalo badan
Kekalau metei wo tuah
Ino sai upo duo
Kiluan adek tuhan

Syukur alhamdulilah

Sekarang jodohmu sampai

Hadir segenap famili

Semoga kalian bernasib baik

Itulah doa kami

Yang dimohon kepada Tuhan

Berdasarkan hasil wawancara yang seluruh perwatin lainnya. Hal tersebut dilakukan pada tanggal 01 Juli 2018, Syaidah terlihat pada kutipan di bawah ini. gelar Suntan Ratu Bayunan mengungkapkan bahwa bait pertama dalam sebuah Pepaccur dapat berupa permohonan izin kepada 


\section{Tabik pun para misi \\ Hikam nondokko sarana \\ Ke kalau dapek nuli \\ Ram dapok bahagia}

b. Bait Isi

Bait isi mencakup beragam variasi Pepaccur yang dapat dilihat dari sudut maksud atau tujuan pemberian Pepaccur. Pengungkapan isi Pepaccur yang beragam dikarenakan beragamnya nasihat yang ingin diberikan kepada kedua mempelai/orang

Pertamo, beribadah

Sembayang wakteu limo

Dang sappai ketinggalan

Kiri munih Fatihah

Tehadep sai kak meno

Kapak sai lagei tengan
Permisi

Ini jadi saran

Siapa tau dapat pasangan

Kita bisa bahagia

yang akan diberi gelar. Isi yang terkandung dalam teks Pepaccur dapat berupa nasihat tentang agama. Kutipan teks Pepaccur terkait nasihat agama dapat dilihat pada kutipan di bawah ini.

Bait isi dalam Pepaccur, juga dapat berupa cerita tentang kehidupan, ceirta tentang proses lamaran, dan cerita lainnya. Isi yang terdapat dalam teks Pepaccur II tentang cerita pasangan laki-laki dan

Masang niku sirok, kukuh mak gubar lagi

Sirok mu sirok lekok, sirok dang gubang lagi

Kite kuti haga nyegok, dapok ridek dija ji

Kita ngebubar sirok, hikam ngusung pulisi

\section{c. Bait Penutup}

Bait penutup merupakan bait terakhir yang terdapat dalam Pepaccur. Bait penutup pada Pepaccur ditandai dengan ungkapan/pernyataan Pepaccur sudah akan

Sijo akhir petuah

Ingekken dang lupo

Akuk jadei anggeuan

Nyo maknono kidah
Ini akhir petuah

Ingat jangan dilupakan

Ambil jadikan pegangan

Apakah maknanya 
Seghem matei di gulo

Pahemken metei sayan
Semut mati karena gula

Tafsirkan oleh kalian

Berikut ini adalah contoh bait permohonan maaf kepada pendengar dan Pepaccur, yang penanda akhirnya berupa permohonan ampun kepada Yang Kuasa.

Lamun wat salah kata,

Munih wat salah susun,

Pisaan sai cak diya,

Hikam bulajagh pantun,

Ya Allah..tabik pun kilu ampun,

Pusekam pandai dia,

Jama kuti sai unyin,

Mehaf pun ngalimpugha
Jika ada salah kata

juga salah susun

pisaan yang katanya

kami belajar pantun

ya Allah mohon ampun

ya kamu tau

pada kalian semua

maaf beribu maaf

\section{Diksi}

Diksi yang digunakan dalam Pepaccur, banyak menggunakan diksi-diksi terkait dengan masalah penyatuan hubungan antara

\section{Syukur Alhamdulilah \\ tigeh judeumeu tano \\ Tano tigeh judeumeu \\ meтugo matei wo rawan}

laki-laki dan perempuan atau biasa disebut dengan pernikahan. Berikut adalah contoh bait Pepaccur, terkait dengan diksi tersebut.

Selain itu, diksi yang digunakan dalam untuk mencintai kekasihnya. Berikut adalah Pepaccur banyak menggunakan diksi-diksi kutipan bait Pepaccur, terkait dengan diksi terkait dengan kisah perjuangan seseorang tersebut.

Inggok nyak minggu likut

Waktu nyak lapah manjau

Badanku jadi liput

Bak ulah kena alau,

Ayah salah penenggis

Adek teduhni nanggis

Badanku rikras-rikris

Di bedak makai linggis,
Syukur Alhamdulilah

sekarang jodohmu sampai

Sekarang jodohmu sampai

semoga kalian bernasib baik
Saya ingat minggu kemarin

Waktu saya ngapel

Badanku jadi kotor

Karena dikejar

Ayah salah pendengaran

Adek dikira menangis

Badanku luka-luka

Dikejar dengan linggis 


\section{Bunyi}

Pepaccur memunyai rima atau pola terlihat pada pembentukan kata-kata dengan bunyi yang selaras. Rima atau pola bunyi bunyi yang serupa di bagian akhir kata. dalam Pepaccur adalah abc/abc dan ab/ab. Berikut adalah contoh Pepaccur dengan rima Keselarasan rima atau pola bunyi dalam atau pola bunyi abc/abc dan ab/ab.

Pepaccur inilah yang membuat efek pola

Syukur alhamdulilah
Tigeh judeumeu tano
Dendeng segalo badan
Kekalau metei wo tuah
Ino sai upo duo
Kiluan adek tuhan

Selain rima, dalam Pepaccur juga ataupun kata yang dibuat oleh orang yang terdapat ritma. Ritma merupakan bentuk ber-Pepaccur. Ritma dalam teks Pepaccur berulang-ulang dari huruf, suku kata, terlihat pada kutipan berikut.

\section{Syukur alhamdulilah \\ Tigeh judeumeu tano \\ Dendeng segalo badan \\ Kekalau metei wo tuah \\ Ino sai upo duo \\ Kiluan adek tuhan}

\author{
Syukur alhamdulilah \\ Sekarang jodohmu sampai \\ Hadir segenap famili \\ Semoga kalian bernasib baik \\ Itulah doa kami \\ Yang dimohon kepada Tuhan
}

Dalam kutipan teks Pepaccur di atas menasihati, mengejek, menyindir, atau terjadi pengulangan huruf 'o'. Pengulangan bersikap lugas hanya menceritakan sesuatu huruf "o" merupakan penanda adanya ritma kepada pembaca.

dalam teks Pepaccur tersebut. Pengulangan huruf 'o' terjadi karena dialek dari narasumber dan tempat pengambilan data.

\section{Nada}

Nada (tone) merupakan sikap penyair terhadap pembaca. Dalam teks puisi terdapat komunikasi antara penyair dan pembaca. Nada terkait dengan sikap penyair terhadap pembaca. Penyair bersikap menggurui,

\author{
Syukur alhamdulilah \\ Sekarang jodohmu sampai \\ Hadir segenap famili \\ Semoga kalian bernasib baik \\ Itulah doa kami \\ Yang dimohon kepada Tuhan
}

Nada (tone) yang terdapat dalam teks Pepaccur adalah memohonkan doa untuk pasangan laki-laki dan perempuan yang akan menikah dan yang diberi gelar. Doa yang diutarakan oleh orang yang ber-Pepaccur adalah agar mereka (pasangan laki dan perempuan) bisa memunyai nasib yang baik dan beruntung dalam kehidupan berumah tangga. Berikut ini merupakan contoh kutipan bait Pepaccur tersebut. 
Syukur alhamdulilah

Tigeh judeumeu tano

Dendeng segalo badan

Kekalau metei wo tuah

Ino sai upo duo

Kiluai adek tuhan
Syukur alhamdulilah

Sekarang jodohmu sampai

Hadir segenap famili

Semoga kalian bernasib baik

Itulah doa kami

Yang dimohon kepada Tuhan

Selain berupa doa, sikap orang yang berkeluarga, harus selalu patuh terhadap ber-Pepaccur juga bisa berupa nasihat. yang lebih tua, mengalah kepada yang lebih Berikut adalah contoh bait Pepaccur yang di muda, jangan membantah perintah orang dalamnya terkandung sikap orang yang ber- yang lebih tua, dan jangan sampai berkata Pepaccur memberikan nasihat. Nasihat yang malas. Hal tersebut dapat dilihat dalam diberikan dapat berupa cara bersikap dalam kutipan bait Pepaccur di bawah ini.

$\begin{array}{ll}\text { Pandai-pandai memalah } & \text { Pandai-pandailah mengalah } \\ \text { Patuh di waghei tuho } & \text { Patuh pada kakak yang sulung } \\ \text { Uyang najin keminan } & \text { Istri kakak maupun bibi } \\ \text { Basing upo perittah } & \text { Apa pun yang diperintah } \\ \text { Dang cawo mak kuwawo } & \text { Jangan mengatakan malas } \\ \text { Ino pebalahan patangan } & \text { Itu perkataan pemalu }\end{array}$

\section{Bahasa Kiasan/Majas}

Majas (figure of speech) merupakan bagian terpenting dalam puisi. Penyair menyampaikan pesan dalam bentuk simbolik. Untuk menangkap pesan-pesan pembaca atau pendengar dipadu dengan bahasa kiasan. Bahasa kiasan berbentuk ungkapan-ungkapan dalam tataran makna konotatif. Bahasa kiasan yang digunakan dalam teks Pepaccur meliputi: alegori, metafora, dan simile.

Bahasa kiasan yang terdapat dalam teks Pepaccur adalah alegori (menyatakan dengan cara lain, melalui kiasan atau

Tano tigeh judeumeu Memugo matei wo rawan Tigeh alam salah mei penggambaran). Kata yang menjadi indikator adalah kata-kata pada bait keempat, kelima, dan keenam. Kata tersebut adalah Tuah nyepik di kukeu (Tuah menyelinap di kuku), Ules ninding dibadan (kebahagiaan selalu menyertai), dan rezekei tawit milet (rezeki senantiasa mengalir). Kata tersebut perupakan kata yang digunakan orang yang ber-Pepaccur, untuk menyatakan tentang nasihatnya dengan menggunakan penggambaran. Kutipan di bawah ini merupakan kutipan yang mendukung pernyataan tersebut.

Sekarang jodohmu sampai Semoga kalian bernsib baik Hingga alam akhirat 


\section{Tuah nyepik di kukeu Ules ninding dibadan Rezekei tawit milet}

Tuah menyelinap di kuku

Kebahagiaan selalu menyertai

Rezeki senantiasa mengalir

Bahasa kiasan yang terdapat dalam menggunakan kata penghubung, layaknya, teks Pepaccur adalah metafora (majas yang ibarat, umpama, bak, bagai dan sebagainya). dibuat dengan frasa secara Implisit tidak berarti namun secara eksplisit dapat mewakili suatu maksud lain berdasarkan pada persamaan ataupun perbandingan). Kata yang menjadi indikator adalah kata-kata pada bait kelima. Kata tersebut adalah Makkung nyak ghantop mejong (belum hangat duduk). Selain itu juga ditemukan majas simile (majas yang membandingkan secara eksplisit (jelas) antara dua hal dengan

\section{Makkung nyak ghantop mejong, Niku adik kak luah, Ku helauko penontong, Ghupa sikop ghik wahwah,}

Ibaragh bunga mawagh, Mekagh dipagi ghani, Sikop mak pantagh tawagh, Ngeguai senang hatiku,

\section{PENUTUP}

Kerangka dalam teks Pepaccur terdiri atas bait pembuka, isi, dan penutup. Dari hasil analisis, semua kerangka Pepaccur tersebut terdapat di dalamnya. Pada bait isi, hampir semua Pepaccur berisikan pemberian nasihat. Namun, diperoleh temuan penelitian dalam salah satu teks Pepaccur, bait isi berisikan uraian cerita untuk mengikat
Kata yang menjadi indikator adalah kata-kata pada bait ketujuh. Kata tersebut adalah Ibaragh bunga mawagh (Ibarat bunga mawar), Mekagh dipagi ghani (mekar di pagi hari). Kata tersebut merupakan kata yang digunakan orang yang ber-Pepaccur, untuk menyatakan tentang nasihatnya dengan menggunakan majas simile. Kutipan di bawah ini merupakan kutipan yang mendukung pernyataan tersebut.

Belum hangat duduk

Kamu adik sudah keluar

$\mathrm{Ku}$ baguskan tatapan

Rupa cantik dan cerah

Ibarat bunga mawar

Mekar di pagi hari

Cantik tak pernah pudar

Membuat senang hatiku

perempuan Lampung dengan cara memberikan logam mulia (emas).

Diksi dalam teks Pepaccur banyak menggunakan diksi-diksi terkait dengan masalah penyatuan hubungan antara laki-laki dan perempuan atau biasa disebut dengan pernikahan. Selain itu, penggunaan diksidiksi terkait dengan masalah ditolaknya cinta seseorang dengan perempuan yang 
dicintainya juga terkadang terdapat dalam teks Pepaccur.

Pepaccur memunyai rima atau pola bunyi yang selaras. Rima atau pola bunyi dalam Pepaccur ini adalah abc/abc, ab/ab, aa/aa, dan a/a. Pola bunyi tersebut membentuk keselarasan bunyi dalam Pepaccur, inilah yang membuat efek pola bunyi yang menarik.

Nada yang terdapat dalam teks Pepaccur sangat beragam. Hal ini bergantung dari apa yang akan disampaikan oleh orang yang ber-Pepaccur. Nada (tone) yang terdapat dalam teks Pepaccur adalah 1) memohonkan doa untuk pasangan laki-laki dan perempuan yang akan menikah dan yang diberi gelar, 2)3 menceritakan tentang proses 'mengikat' perempuan untuk laki-laki, 3) menceritakan ditolaknya cinta seseorang dengan perempuan yang dicintainya, 4) berlapang dada dalam menyikapi masalah tersebut dan 5) memberi tahu tentang perjuangan mencintai seseorang.

Majas (figure of speech) merupakan bagian terpenting dalam puisi. Penyair menyampaikan pesan dalam bentuk simbolik. Untuk menangkap pesan-pesan pembaca atau pendengar dipadu dengan bahasa kiasan. Bahasa kiasan berbentuk ungkapan-ungkapan dalam tataran makna konotatif. Bahasa kiasan/majas yang terdapat dalam teks Pepaccur meliputi; alegori, metafora, dan simile. Bahasa kiasan ini digunakan sebagai bentuk simbolik orang yang ber-Pepaccur untuk memberikan nasihat kepada orang yang diberi nasihat.

\section{DAFTAR RUJUKAN}

Armina. 2014. Structures of The West Lampung Wayak's Oral Literarure. http://artikel.ubl.ac.id/index.php/i cel/article/download/293/295 (tanggal akses 3 Juni 2017)

Sanusi, Effendi. 2010. Sastra Lisan Lampung. Bandar Lampung: Universitas Lampung.

Hadikusuma, Hilman. 2010. Bahasa Lampung. Bandar Lampung: PT. Fajar Agung.

Malik, S.Harto. 2012. Lohidu sebagai Ragam pantun pada Masyarakat Gorontalo (Disertasi). Jakarta: Universitas Negeri Jakarta.

Pradopo, Rachmad Djoko. 2010. Pengkajian Sastra. Yogyakarta: Gadjahmada University Press.

Sukmawati dkk. 2014. Pepaccur pada Masyarakat lampung Pepadun dan Kelayakannya sebagai Materi Pembelajaran. http://jurnal.fkip. unila.ac.id/index.php/BINDO/arti cle/download/5825/3590 (tanggal akses 1 Juni 2017.

Waluyo, J. Herman (2013). Apresiasi Sastra: Untuk Pelajar dan Siswa. Jakarta: Gramedia Pustaka Utama. 